\title{
On the Humanity of the Enemy of Humanity
}

\section{A Response to My Critics}

\author{
David Luban
}

\section{Introduction}

I am deeply grateful to the participants in this symposium for their thoughtful and instructive responses to my essay. That they devoted so much effort to this project reassures me that the figure of the hostis generis humani - 'HGH' for short - touches a nerve and merits our attention. That is so, even though the other participants have serious misgivings about the HGH concept itself, and find flaws in my treatment of it.

Before offering specific rejoinders to each of them, let me explain how I understand my project in the essay, and what is at stake. Why is reflecting on the HGH concept worthwhile? After all, I agree with my critics that HGH has always been an easy concept to abuse in politically horrifying ways. Furthermore, very few international tribunals actually make use of the legal formula hostis generis humani. If the formula is dangerous and unnecessary, why not simply drop it from the lexicon of international law?

My answer is that even if the legal formula is unnecessary, the theoretical concept is not. If we delete the HGH concept, advocates of international criminal accountability will need to find some alternative conceptualization of core crimes and their perpetrators that signifies two propositions central to international criminal justice:

1. Core crimes are a matter of concern to distant strangers, and not only locally.

2. Something in the nature of core crimes - a 'heinousness factor,' whatever that may turn out to be - makes them special, and explains why distant strangers should care about them.

'Enemy of all humanity' captures both points, with the intense word 'enemy' signifying the heinousness factor and '... of all humanity' indicating universal concern. There is a third point as well:

\section{The word 'humanity' matters.}

'Humanity' is not merely shorthand for the set of all human beings, for the perpetrators, their henchmen, and their supporters may number in the millions, and in their eyes the perpetrator is no enemy. Thus, if 'humanity' is used only descriptively, propositions like Hannah Arendt's claimed discovery of a 'new type of 
criminal, who is in actual fact hostis generis humani ${ }^{1}$ would be trivially false. In Arendt's proposition, 'humanity' has normative significance: it assumes a theory of how humans ought to conceive of ourselves and our status. ${ }^{2}$ And living up to the name 'humanity' means putting that theory into practice. 'Humanity' names the multitude committed, for various reasons, to a collective cosmopolitan project of responsibility-taking and accountability.

Hostis generis humani is a compact phrase that commits its utterers to these three propositions - about universality, about heinousness, and about humanity. Why do we need such a concept? Because without the three propositions, we will have no justification for international criminal justice (ICJ for short). Ultimately, we will have no justification for transcending tribalism and regarding ourselves as members of a broader community called 'humanity.' Let me explain why I think this.

In one of his interviews for Shoah, Claude Lanzmann asked a peasant what his reaction was when he saw human ash from the nearby crematoria at a death camp. The answer: 'When I cut my finger, I feel it. When you cut your finger, you feel it.' Michael Ignatieff remarks: 'The man's reply takes us to the heart of the problem (...) Why is a crime committed against Jews or any other human group a crime against those who do not belong to that group?'3 Contrast the peasant's response with an early invocation of 'humanity': Terence's beautiful line 'Homo sum, humani nihil a me alienum puto' - I am human, and nothing human seems alien to me. ICJ depends on the intelligibility of Terence's outlook and the reasons for preferring it to that of Lanzmann's peasant - and 'humanity' is our shorthand for this outlook.

It is no secret that ICJ is in trouble in today's world of reactionary nationalism, shrinking concern for human rights, and defiant politicians who despise international institutions and reject any effort to hold leaders accountable to outsiders. Five years ago, I contributed to a symposium on whether the world was losing enthusiasm for ICJ; I remained hopeful. ${ }^{4}$ Today, five years later, few would deny that the prognosis for ICJ has gotten worse. The ad hoc tribunals have nearly wrapped up their business, and no successors are on the horizon for singular

1 Hannah Arendt, Eichmann in Jerusalem: A Report on the Banality of Evil, rev. ed. (London: Penguin Classics, 1963), 263.

2 For example, Arendt's own theory identifies the human status with human plurality: the differentiation of human beings into many peoples. Eichmann, as a génocidaire, was an enemy of humanity because genocide is an assault on human plurality. Other theorists of international criminal justice have different theories of what normative commitments constitute 'humanity.' For Raphael Lemkin, who coined the word 'genocide,' it is a commitment to universal civilization; for Nuremberg prosecutor François de Menthon, it is a commitment to the spiritual dimension of human life. For many supporters of international criminal justice, it is a commitment to the world-wide rule of law, or to global justice, or to liberal internationalism.

3 Michael Ignatieff, 'Lemkin's Word,' The New Republic, https://newrepublic.com/article/62613/ lemkins-word (accessed January 8, 2019).

4 David Luban, 'After the Honeymoon: Reflections on the Current State of International Criminal Justice,' Journal of International Criminal Justice 11 (2013): 505-15. 
atrocities in Syria and elsewhere. The ICC is under political attack from east, west, and south. For cynically self-interested reasons, some states and their leaders reject the idea that the ICC, or any other tribunal created by multinational treaty, has authority over them. They deny that the ICC speaks for the international community, or has any powers transcending those of a single state. This issue is currently under litigation, and enemies of the ICC are eager to see it deflated and defanged. Even some thoughtful commentators whose sympathies align with ICJ have become skeptical of ICJ in practice; they criticize it for inefficacy, self-righteousness, unintended perverse consequences, selective prosecution, and politicization.

Despite their criticisms, many of which are well-taken, the intuitions that drive the ICJ project are hard to ignore, and should not be ignored:

- that there is something obscene about impunity for atrocity crimes;

- that justice requires accountability;

- that claims of state sovereignty must not serve as shields against accountability;

- that a world which ignores atrocity crimes is a meaner and worse world - a world less fit for human habitation, to paraphrase Arendt.

The core crimes in international criminal law are all crimes of political violence, committed by states or state-like entities. Their perpetrators long justified them through slogans like raison d'état or Kriegsraison, or mysticisms about the sanctity and superiority of the race. Such slogans and mysticisms imply that violence on behalf of states and peoples is not to be judged by ordinary moral standards and is in this sense beyond good and evil. Sovereigns are like gods, and their violence is not to be judged by profane moral standards. ${ }^{5}$ As I conceive of the ICJ project, its heart is a radical effort to shift our moral imaginations away from this toxic political theology. Sacred violence must be reimagined as profane violence, and ICJ's project is to translate political violence out of the realm of idolatry and into the realm of ordinary thuggery. ${ }^{6}$ ICJ performs this translation through expressive means: investigations, trials, and punishments. If today we have gotten used to labeling mass atrocities 'genocide,' 'war crimes,' and 'crimes against humanity,' it is because the ICJ project has partly succeeded.

It is precisely because the project matters that it is worthwhile reflecting on its basic assumptions about universality, heinousness, and humanity. None is self-

5 See Paul Kahn, Sacred Violence: Torture, Terror, and Sovereignty (Ann Arbor: University of Michigan Press, 2008), and Moshe Halbertal, On Sacrifice (Princeton: Princeton University Press, 2012), 63-113.

6 So I have argued in several papers: 'Fairness to Rightness: Jurisdiction, Legality, and the Legitimacy of International Criminal Law,' in The Philosophy of International Law, ed. Samantha Besson and John Tasioulas (Oxford: Oxford University Press, 2010), 569-88; 'State Criminality and the Ambition of International Criminal Law,' in Accountability for Collective Wrongdoing, eds. Tracy Isaacs and Richard Vernon (Cambridge: Cambridge University Press, 2011), 61-91; and 'After the Honeymoon.' 
evident; all raise deep questions. Why should some acts of political violence concern all humanity rather than a single community? What makes those crimes different from other crimes? What kind of normative project deserves the label 'humanity'?

Let me be clear: I am not arguing that the phrase 'enemy of all humanity' answers these questions. Rather, it invites us to search for the answers. Whatever answers we give will be our explanation or vindication of ICJ - in Kantian terminology, our transcendental deduction answering the quaestio juris 'what entitles us to international criminal justice?' Hostis generis humani is a suggestive label, and I agree with my commentators that mere labels are dispensable - provided that the thing to which the label attaches remains intact. What fascinates me in the history of the HGH concept is how, as jurists inherited the term from their predecessors, it gradually changed its significance to draw ever closer to modern international criminal justice.

Louis Sicking argues that many of these juristic appropriations involved misreadings and misunderstandings. ${ }^{7}$ That may well be true - and indeed, my essay draws a similar conclusion. I argued that tracing the modern core criminal back to the pirate of Roman and medieval times makes HGH a linguistic false friend, because the better analogy is to ancient tyranny rather than ancient piracy. ${ }^{8} \mathrm{I}$ also noted that applying the HGH label to slave traders was a legal fiction to enable navies to board them in peacetime as if they were pirates - in other words, it was a creative misreading of the law. ${ }^{9}$

In the end, I do not think this matters. It would matter if the sole source of juridical authority comes from precedents, accurately read in their historical context. In fact, jurists perpetually refashion legal concepts and language, and their authority derives not from historical fidelity, but from the power of their innovations, measured partly by widespread acceptance of the innovation, and partly by its usefulness. As Oliver Wendell Holmes, Jr. explained in 1881,

'The customs, beliefs, or needs of a primitive time establish a rule or a formula. In the course of centuries the custom, belief, or necessity disappears, but the rule remains. (...) The rule adapts itself to the new reasons which have been found for it, and enters on a new career. The old form receives a new content, and in time even the form modifies itself to fit the meaning which it has received. ${ }^{\prime 10}$ (2018): 7-10.

8 Luban, 'The Enemy of All Humanity,' Netherlands Journal of Legal Philosophy 2: (2018): 126.

9 Luban, 'Enemy of All Humanity,' 14.

10 Oliver Wendell Holmes, The Common Law, ed. Mark DeWolfe Howe (Boston: Little, Brown, 1963), 8; see also Holmes, 'The Path of the Law,' Harvard Law Review 10 (1897): 469-73. For a contemporary philosophical argument along these lines, see Robert B. Brandom, Reason in Philosophy: Animating Ideas (Cambridge, MA: Harvard University Press, 2009), 84-90. 
On this familiar line of argument about juristic authority, it does not matter whether the pirate analogy, invoked to justify universal jurisdiction over today's core international crimes, misunderstands the historical functional role of universal jurisdiction in the suppression of piracy. The fact that the old formula has begun a new career in a changed world is not an argument against the new career - just the contrary. The new reasons support its authority rather than undercutting it. ${ }^{11}$

Marc de Wilde describes my essay as an 'attempt to revive the "enemy of all humanity” concept in international criminal law.' 12 This is not quite how I see it. My proposal is not to revive $\mathrm{HGH}$ as a legal concept, but rather to reflect on it as a theoretical concept that captures some authentic experiences of modern political crime that raise the issues of universality, heinousness, and humanity. Perhaps it will clarify matters to distinguish three uses of 'enemy of all humanity':

1 As a doctrinal concept within the law, defined legally and giving rise to specified legal consequences.

2 As a political concept, used rhetorically by political leaders.

3 As a theoretical concept.

As I discuss below, I agree with both Sofia Stolk and Marc de Wilde that 'enemy of all humanity' is a dangerously combustible political concept. It is easily abused by demagogues to demonize their enemies and justify political murder. As a legal concept, HGH should be used only in in the context of fair trials that offer full protection to defendants (what I have elsewhere called champagne-quality due process ${ }^{13}$ ). And while international lawyers can do without the phrase 'hostis generis humani', I also maintain that they do not need to do without it when they wish to invoke universality of concern and heinousness of the crime. But they must be careful to prune away any implications that condemning someone as hostis generis humani makes them eligible for extrajudicial killing. That implication imports the toxic political concept into law, and the law must turn back the toxic import at the border.

Finally, as a theoretical concept, HGH requires us to reflect on the basic assumptions of international criminal justice - and, to the extent it does so, it stands at the threshold of a philosophy of international criminal law. There lies its true value. To repeat my point: defenders of ICJ may expunge the phrase, but they need the concept.

11 Quoting Holmes again, 'It is revolting to have no better reason for a rule of law than that so it was laid down in the time of Henry IV. It is still more revolting if the grounds upon which it was laid down have vanished long since, and the rule simply persists from blind imitation of the past.' Holmes, 'Path of the Law,' 469.

12 Marc de Wilde, 'Enemy of All Humanity: The Dehumanizing Effect of a Dangerous Concept,' Netherlands Journal of Legal Philosophy 2 (2018): 159.

13 Luban, 'Fairness to Rightness,' 579. 


\section{Response to Sofia Stolk}

Writing my essay, I was surprised to find how few international judicial decisions actually used the literal phrase 'hostis generis humani'. One of Stolk's valuable contributions to this symposium is broadening the universe of discourse to include not only judicial decisions, but prosecutors' opening statements as well. She confirms that prosecutors in the international tribunals also refrain from literal HGH-talk - but as she analyzes their statements, she finds echoes of the concept in different words, for example when prosecutors denounce the defendant's savagery or barbarism. Linguistically, the savage and the barbarian are defined by contrast with us - the civilized ones, the true bearers of humanity. Similarly, prosecutors implicitly use HGH-talk whenever they accuse defendants of dehumanizing their victims. Stolk warns that through those accusations 'the humanity of the defendant is questioned. ${ }^{14}$ The accusations become instances of, rather than condemnations of, dehumanization. That makes them unconsciously and ironically self-referential.

The defendant, too, is a human being, and Stolk fears that the HGH construct, with its talk of radical evil and barbarism, excludes the defendant from the human community. Stolk warns that such exclusion is not only dangerous, but essentially false when we consider low-level defendants and especially child soldiers. The HGH label 'cannot account for all the different shades of evil; some shades that fall into the realm of the human, some tending towards inhuman or transcendental evil.' ${ }^{15}$

Stolk's critique would be valid, I think, if the prosecutor pretends that terms such as 'savagery,' 'barbarism, ' 'radical evil,' 'dehumanizing,' or other rhetorical cousins of HGH provide a full description of defendants and their conduct. Admittedly, prosecutors have an obvious motivation for hyperbolically - and reductively portraying defendants as monsters. ${ }^{16}$ Reductive and inflammatory rhetoric is an occupational hazard of prosecution. But there is no reason for judges and onlookers to accept such reductions. It is judges' job and our job to understand that three-dimensional human beings, no different in most ways from the rest of us, can perform acts of unfathomable cruelty. All the shades of evil 'fall into the realm of the human'; none of them represents transcendental evil, if by that phrase Stolk means evil so monstrous that we cannot imagine a human being committing it.

Sofia Stolk, “'Cruel Men Can Do Kind Things and Kind Men Can Do Cruel Things”: Reconsidering the Enemy of Humanity in Contemporary International Criminal Trial Discourse,' Netherlands Journal of Legal Philosophy 2 (2018): 151.

15 Stolk, “'Cruel Men," 154.

16 Rhetorical harshness is understandable when we consider the burden of proof prosecutors must meet. To prove genocide, they must show that the defendant intended to destroy a group as such; to prove crimes against humanity, they must show that the defendant knew that his or her crime was part of an attack on a civilian population; to prove crimes of obedience, they must show that the defendant obeyed a manifestly illegal order. Small wonder that their rhetoric tends to be hyperbolic and reductive. 
Fortunately, no legitimate criminal trial begins and ends with the question is this person an enemy of all humanity?' The human nuances that Stolk calls 'shades of evil' appear throughout the criminal process whenever a court considers mens rea, modes of liability (principal, accessory, Hintermann, abettor), excuse and justification defenses, and overall culpability for sentencing purposes. Perhaps, then, the dangerous reductivism that worries Stolk comes from artificially isolating the prosecutor's opening statement, rather than from the concept of hostis generis humani.

If there is any novelty in my treatment of $\mathrm{HGH}$, it is that I want to argue that subjecting the hostis generis humani to legal accountability in a fair trial does the opposite of dehumanizing her. In this argument, I place a great deal of weight on an insight of Arendt's: that 'the idea of humanity (...) has the very serious consequence that in one form or another men must assume responsibility for all crimes committed by men and that all nations share the onus of evil committed by all others. ${ }^{17}$ As Arendt goes on to explain, assuming such a responsibility means recognizing that the criminal, the $\mathrm{HGH}$, is not a monster, a devil, or a beast. Rather, the HGH is formed of the same crooked timber as you and me. Putting the HGH on trial is an act of inclusion, not of exclusion. It is a version of Terence's 'nothing human is alien to me' sung in a moral and legal key. Of course, plenty of humans regard others as alien to them. Terence's adage represents a commitment to regarding nothing human as alien to him, not a logical truth. As Arendt elaborates this commitment, we must assume responsibility and share the onus of evil committed elsewhere. It requires us to reclaim the enemy of humanity by calling him or her to account. And putting the HGH on trial is our mechanism for calling to account.

Stolk objects that there is something condescending and false about such acts of inclusion: 'to depict a humanity that is capable of 'reclaiming' this enemy gives the impression of an almost gracious act; an act that is performed by an innocent

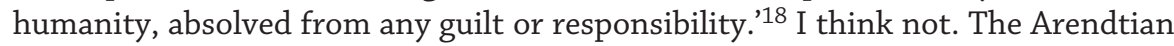
insight that I have adopted rejects the idea of an innocent humanity. To be sure, we are innocent of the specific crimes charged against the defendant: we did not do it, the defendant did (in which case we are not, strictly speaking, absolved from guilt - we simply are not guilty). But we are not 'holier than thou' beings putting an alien being on trial. Nor does reclaiming the HGH by putting him or her on trial absolve the judges of responsibility. It is a way of taking responsibility.

But why call the defendant an enemy of humanity? The answer lies in the ideas I described earlier: it is a way of saying that the deed was so heinous that it is of

17 Arendt, 'Organized Guilt and Universal Responsibility,' originally published in Jewish Frontier in 1945, reprinted in Arendt, Essays in Understanding, 1930-1954, ed. Jerome Kohn (New York: Harcourt-Brace, 1994), 131. Arendt found this idea important enough to repeat it, with only a minor change in wording, in The Origins of Totalitarianism, 3rd ed. (New York: Shocken Books, 2004), 303. There, it appears in her analysis of tribalism and racism, which 'are the very realistic, if very destructive, ways of escaping this predicament of common responsibility.' 
universal, not only local, concern; and that calling the doer to account is the task of 'humanity,' meaning all who accept the project articulated by Terence and Arendt. To this we might add another overlay of meaning in the phrase hostis generis humani: What makes core criminals 'enemies of humanity' is that the kind of violence they commit rejects the very idea that there is a cosmopolitan project of humanity.

\section{Response to Marc de Wilde}

Marc de Wilde sees a wider gap between his genealogy of the HGH concept and mine than I do. I regard his account as a complement to mine, because of his welcome analysis of early modern jurists who, for reasons of space, I glossed over. ${ }^{19}$ The main substantive difference is in our interpretations of Cicero's prosecution of Verres. Cicero accused Verres of colluding with pirates to such an extent that he himself deserved that label. I see that accusation as further evidence of Cicero's singular hostility toward pirates. ${ }^{20}$ But de Wilde sees something more sinister: the political use of HGH-talk against a fellow Roman citizen, prefiguring its politicized use by radicals in the French Revolution. I agree that Cicero, an ambitious young politician, probably had a political motive for prosecuting Verres (who by all accounts was indeed guilty as charged). But Cicero's was a regular criminal prosecution, not an incitement to extrajudicial murder, and the upshot was Verres's exile from Rome, not his execution.

More important than disagreements about the history is de Wilde's concern that the political use of $\mathrm{HGH}$-talk is an invitation for tyrannical leaders to create parallel systems of justice to deal with their political enemies, whom they demonize as 'enemies of humanity.'21

Stolk and de Wilde persuade me that this is a very real danger. The HGH concept therefore ought to be restricted to ICJ, and excluded from domestic use, because the danger of weaponizing it against domestic political enemies is too high. ${ }^{22}$ That restriction makes sense, because, as I argued above, the point of hostis generis humani as a theoretical concept is in ICJ.

19 My essay did offer passing references to Grotius, Bacon, Gentili, Wolff, and Blackstone, but not to Belli or Ayala; de Wilde's treatment of them and his more extensive treatments of Gentili and Grotius are useful, but I do not see them in any way contradicting the genealogies of the HGH in my essay. That our treatments overlap in many ways is unsurprising: both of us draw significant inspiration from the important books by Edelstein, Heller-Roazen, and Rubin, as well as from de Souza's history of piracy in the Greco-Roman world.

20 See footnote 9 in my essay. De Wilde also thinks I overlooked Cicero's definition of the pirate as a 'common enemy of all peoples and nations.' De Wilde, 'Enemy of All Humanity,' 163. In fact, I quote the definition, in both English and Latin, in footnote 9.

21 De Wilde, 'Enemy of All Humanity,' 169, 173, 174.

22 An exception to my proposed 'no domestic use of HGH' might be when domestic legal systems are recruited to try international crimes under universal jurisdiction. 
Does it still create the danger of a parallel system of justice? Well, the international criminal tribunals are a parallel system of justice, and unapologetically so. They were created because domestic criminal justice systems cannot be counted on to produce justice rather than bad-faith exonerations of war criminals - the lesson of Leipzig. Elsewhere, I have argued that their legitimacy arises internally, from the fairness of their processes and humaneness of their punishments. These relatively weak, decentralized institutions pose very little danger of despotic abuse. ${ }^{23}$ That sharply distinguishes international tribunals from Star Chambers and the Volksgerichthof.

I recognize that some well-informed critics of ICJ disagree. Yet can we identify any cases of wrongful conviction in the ICC or the ad hoc tribunals? We have heard many accusations of wrongful conviction, but coming from defendants like Charles Taylor and Hissène Habré they are unpersuasive. Without evidence that ICJ has, as a matter of empirical fact, begun to follow what de Wilde calls 'the logic of exceptionalism, ${ }^{24}$ I do not agree that parallel systems of justice are intrinsically bad. All parallel systems are not created equal.

\section{Response to Louis Sicking}

Professor Sicking adds to the 'Ciceronian paradigm' of piracy I developed in my essay an 'Augustinian paradigm' that he believes I overlooked. By 'Ciceronian paradigm' he means the heavily moralized condemnation of pirates as common enemies of humanity who lie outside the realm of ordinary human obligation. The Augustinian paradigm is far less moralistic. It draws no in-principle distinction between 'kingdoms' and 'great robber bands,' as Augustine memorably writes in The City of God. Within the Augustinian paradigm, piracy was 'not necessarily reprehensible,' and by some accounts it was 'a normal way to earn a living. ${ }^{25}$ For long stretches of time, Sicking argues, the Augustinian paradigm prevailed, and piracy was only illegal when committed by an enemy. Thus, he argues, my genealogy imposes a false continuity on a discontinuous history by stitching together temporally remote Ciceronian-paradigm texts and neglecting the Augustinian paradigm. 
I accept Sicking's correction. ${ }^{26}$ But for Holmesian reasons I set out earlier and shall not repeat, I do not think it matters if latter-day jurists misunderstood the history of the concept they were appropriating. Those later appropriations are 'strong misreadings' that fuel the creative legal process. As long as the misreading has theoretical and practical justification, the bare fact that it is a misreading should not undermine its authority.

A case in point is universal jurisdiction over core international crimes. Sicking endorses Eugene Kontorovich's critique of modern universal jurisdiction, which I briefly criticized in my essay. Kontorovich argues that historically, the reason for universal jurisdiction over piracy had nothing to do with how evil piracy is. It had to do only with the practicalities of suppressing piracy (which states did not do when the pirates were their own privateers). This is pure Augustinian paradigm. But modern universal jurisdiction over core crimes rests on how evil the crimes are - a Ciceronian approach. For Kontorovich, the upshot is that universal jurisdiction has less legitimacy than its supporters believe.

The mistake is that universal jurisdiction's legitimacy does not depend on the historical accuracy of the pirate analogy. It depends on the usefulness of the pirate analogy. Analogies, like metaphors, are made, not found. When Gideon Hausner invoked the pirate analogy and called Eichmann hostis generis humani, his argument was no different from his reference to Cain: he was asking the judges to apply a category previously used for pirates and fratricides to a perpetrator of genocide. So too when Rhonda Copelon and Peter Weiss applied the pirate analogy and the HGH label to torturers. If these were misreadings of legal history, they were strong misreadings.

\section{Response to Antony Duff}

I framed the final portion of my essay with Antony Duff's 'Authority and Responsibility in International Criminal Law' very much in mind. ${ }^{27}$ Although I disagreed with that essay's critique of the HGH concept, I drew inspiration from Duff's proposal that 'humanity' is an embryonic moral community, not a political community. This moral community consists of human beings who accept the responsibility of judging atrocity crimes across borders, even though that requires accepting

26 I have doubts about attributing this paradigm to Augustine. I do not take Augustine to be saying that pirates are as legitimate as kings, but rather that unjust kings are as bad as pirates. Sicking ignores the first two words of Augustine's quotation: without justice. An unjust king or tyrant is like a robber. A just ruler is entitled to use violence to suppress injustice. See, e.g., Augustine's Against Faustus the Manichean, Book XXII, chs. 74-75, 78, in The Ethics of War: Classic and Contemporary Readings, eds. Gregory M. Reichberg, Henrik Syse, and Endre Begby (Hoboken: Blackwell, 2006), 81-82; so too Questions on the Heptateuch, Book VI, ch. 10, in The Ethics of War, eds. Reichberg et al., 82. Such a ruler is not at all like a pirate, for the ultimate goal of a just war is a just and harmonious peace. E.g., Augustine, The City of God, Book XV, ch. 4, Book XIX, ch. 11-12.

27 Antony Duff, 'Authority and Responsibility in International Criminal Law,' in The Philosophy of International Law, eds. Samantha Besson and John Tasioulas (Oxford: Oxford University Press, 2010), 593-97, 602-3. 
that the perpetrator is one of us, that is, not all that different from me. And, I added, there is nothing illicit about the moral community ('humanity') employing existing state and international institutions to advance its project.

Duff remains unpersuaded. He maintains that a moral community is simply the wrong sort of thing to produce international criminal law. Only political communities can produce criminal law. ${ }^{28}$ To this, my response is that Duff's categorical distinction between moral and political communities is too sharp. My own view is more akin to legal pluralism: societies contain multiple coexisting legal and quasi-legal systems at work simultaneously, under the umbrella supervision of the state. Even talk of 'umbrella supervision' may be too statist, because it assumes a strong and high-functioning sovereign exercising a monopoly on the legitimate use of violence. Not all states are strong and high-functioning. For that matter, even strong states delegate important functions to non-state institutions: think of private prisons and private security contractors - but also of self-regulating industries. Given the pervasiveness of delegation, it is far less clear than Duff supposes that only political communities can competently create law. We can see legal pluralism at work in international criminal law, where lawmaking is heavily influenced by non-governmental institutions such as the ICRC and Amnesty International. The ICC formally allows NGOs in as official observers at Assembly of States Parties meetings, and although they do not vote, the NGOs exert powerful influence. Perhaps Duff would respond that while pluralism may be descriptively true, it is normatively unsound. I disagree, but rather than pursue the issue here, I will simply flag it as a point of honest disagreement.

Duff argues that the right international community to create ICJ is the community of states, not of 'humanity,' and states must be the first responders to their own atrocity crimes. Global justice is second-best justice; domestic justice within states is first-best. ${ }^{29}$ For this reason Duff endorses the ICC's principle of complementarity ('subsidiarity' in his terminology). Complementarity recognizes that criminal justice has healing power in shattered communities if it functions locally, not globally. ${ }^{30}$ Only if local justice fails should the international community step in. 'The ICC then speaks in the name of the community of nations, on behalf of the citizens of the nation in which the crime was committed. ${ }^{31}$

Duff's argument for local justice rings true, but it is only half the truth. As explained above, I view the cardinal aim of ICJ to be the transformation of our political imaginary of extreme political violence. That project addresses a global rather than local audience. Scholars recognize a global-local dilemma confronting

Antony Duff, 'Crimes Against Humanity and Hostes Generis Humani,' Netherlands Journal of Legal Philosophy 2 (2018): 141.

29 Duff, 'Crimes Against Humanity,' 144.

30 That is not why the drafters included complementarity in the Rome Statute. Complementarity was a device to ensure that ICC members retained control over the ICC's power to prosecute, and it is doubtful that the ICC would exist if it did not include complementarity. But this is not relevant to Duff's strong argument.

31 Duff, 'Crimes Against Humanity,' 147. 
ICJ. ${ }^{32}$ Who is its audience, the local victim-perpetrator community or the international community? What is its aim, reconciliation or justice? I have no easy answer to this question, but I strongly maintain that the global mission is both crucial and distinctive for ICJ.

An example will illustrate the tension. In Sierra Leone's civil war, all factions, including the Civil Defense Force that defended the government, committed war crimes. After the Special Court for Sierra Leone convicted leaders of the Civil Defense Forces, the judges considered whether the fact that they were defending the lawful government should justify a more lenient sentence. Reportedly, that was the sentiment on the streets and the Trial Chamber agreed. ${ }^{33}$ The Appeals Chamber reversed - rightly, in my view. Under international law, a war crime is a war crime regardless of which side commits the crime. Local sentiment should not be allowed to undermine the still-fragile global commitment to an impartial jus in bello. ${ }^{34}$ Here, the global rightly prevailed over the local.

\section{Conclusion: we have met the enemy and he is us}

All four commentators are concerned that attaching the label 'enemy of humanity' to the perpetrators of atrocity crimes demonizes and dehumanizes them. It excludes them from humanity. My response throughout has been, first, to acknowledge that the danger is genuine; second, to insist that the right response to the danger is to cabin the legal use of the HGH concept to meticulously fair trials; third, that something equivalent to the theoretical HGH concept is baked into the enterprise of international criminal justice, whatever label we use for that concept; and fourth, that calling core crime perpetrators to account in a legal process is a way of including them in humanity, rather than excluding them.

A few concluding words on the fourth point: Walt Kelly (1913-1973) was an American cartoonist and humorist. For thirty years, Kelly drew an off-beat and warm-hearted commentary on the human condition, in the form of a comic strip whose characters were talking animals living in an American swamp. ${ }^{35}$ Kelly was also a lifelong opponent of the political hatred and fearmongering that gives rise to atrocity crimes. At the height of anti-communist hysteria in the early 1950s, Kelly caricatured the Red-baiting senator Joseph McCarthy as a sinister bobcat named Simple J. Malarkey who arrived in the swamp to make trouble. Criticized for introducing political satire into a daily comic strip, Kelly responded: International Courts, eds. Nienke Grossman et al. (Cambridge: Cambridge University Press, 2018), 62-82.

33 Prosecutor v. Fofana, Case No. SCSL-04-14-T, Judgment, § 86 (Oct. 9, 2007).

34 Prosecutor v. Fofana, Case No. SCSL-04-14-A, Judgment, §§ 529-35 (May 28, 2008).

35 The comic strip bore the name of one of Kelly's characters, Pogo the Possum. Happily, all his Pogo strips are now published in a five-volume compendium: Walt Kelly, Pogo: The Complete Syndicated Comic Strips (Seattle, WA: Fantagraphics Books, 2011-18), vol. 1-5. 
'Traces of nobility, gentleness and courage persist in all people, do what we will to stamp out the trend. So, too, do those characteristics which are ugly. (...) It remains true that those things which make us human are, curiously enough, always close at hand. Resolve then, that on this very ground, with small flags waving and tinny blasts on tiny trumpets, we shall meet the enemy, and not only may he be ours, he may be us. Forward! 36

Kelly echoed the final thought in a famous and iconic cartoon panel. The title character of his comic strip, Pogo the Possum, sits pensively on a tree root and remarks, in something approaching wonderment, 'We have met the enemy and he is us.' I could not get Pogo out of my head while I was writing my essay and this response - tinny blasts on tiny trumpets. ${ }^{37}$

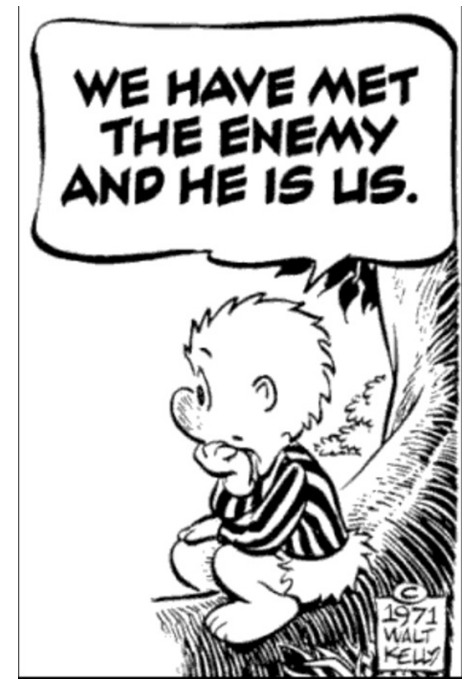

36 Walt Kelly, The Pogo Papers (Boston: Gregg Press, 1953). The reference is to Commodore Perry's laconic message after an 1813 naval victory: 'We have met the enemy and they are ours.'

37 This famous Pogo panel - which the environmental movement has long used as a poster-may be found at https://www.google.com/search?tbm=isch\&source=hp\&biw=1440\&bih=693\&ei= NOw0XOmfI-G1ggfD9qRI\&q=pogo+we+have+met+the+enemy+and+he+is+us\&oq=p\&gs_l=img. 1.0.35i3912j018.1650.1650..4173...0.0..0.155.155.0j1.....1....1..gws-wiz-img.....0.Q_oakw_ Pi84\#imgrc=QtMNEFOBwNfdlM: (accessed January 8, 2019). 